\title{
Vero Cytotoxin Production and Presence of VT Genes in Escherichia coli Strains of Animal Origin
}

\author{
By H. R. SMITH,${ }^{1 *}$ S. M. SCOTLAND, ${ }^{1}$ G. A. WILlSHAW,${ }^{1}$ C. WRAY, ${ }^{2}$ \\ I. M. MCLAREN,$^{2}$ T. CHEASTY ${ }^{1}$ AND B. ROWE ${ }^{1}$ \\ ${ }^{1}$ Division of Enteric Pathogens, Central Public Health Laboratory, Colindale Avenue, \\ London NW9 5HT, UK \\ ${ }^{2}$ Central Veterinary Laboratory, Weybridge, Surrey KT15 3NB, UK
}

(Received 16 July 1987; revised 23 October 1987)

\begin{abstract}
Vero cytotoxin (VT) production has been studied in 34 Escherichia coli strains isolated from animals with enteric diseases. The strains were tested by DNA hybridization with probes for VT1 and VT2 sequences and also in toxin neutralization experiments with specific antisera. Twenty bovine strains, belonging to nine different $O$ serogroups, produced VT1 or VT2 but not both toxins. In contrast, all 14 porcine strains of four different $O$ serogroups produced VT2 only. Six of these porcine strains, belonging to serogroups O138, O139 and O141, were isolated from cases of oedema disease. In general, the porcine isolates produced toxin at a lower level than the bovine strains.
\end{abstract}

\section{INTRODUCTION}

Production of a cytotoxin active on Vero cells, termed Vero cytotoxin (VT), has been detected in strains of Escherichia coli from cases of human and animal disease (Konowalchuk et al., 1977). The Vero-cytotoxin-producing E. coli (VTEC) of human origin belong to a number of different $\mathrm{O}$ serogroups, particularly $\mathrm{O} 157$. The $\mathrm{VT}^{+} \mathrm{O} 157$ strains have been associated with cases of diarrhoea, haemolytic uraemic syndrome (HUS) and haemorrhagic colitis (HC) in Canada, USA and Britain (Karmali et al., 1983; Riley et al., 1983; Scotland et al., 1988; Smith et al., 1987). VTEC have also been isolated from calves and pigs with enteric diseases. The strains of bovine origin belong to a large number of $\mathrm{O}$ serogroups and have been isolated from cases of diarrhoea and also from healthy animals (Sherwood et al., 1985; Mohammad et al., 1985, 1986). $\mathrm{VT}^{+}$strains of serogroups O138, O139 and $\mathrm{O} 141$ have been associated with post-weaning diarrhoea and oedema disease in pigs (Kashiwazaki et al., 1980, 1981; Dobrescu, 1983; Smith et al., 1983; Blanco et al., 1983; Gonzalez \& Blanco, 1985).

Attempts to neutralize VT with specific antisera have shown that there is more than one VT (Konowalchuk et al., 1977; Smith et al., 1983; Scotland et al., 1985; Karmali et al., 1986). VT produced by strains of human origin such as $\mathrm{H} 19$ and $\mathrm{H} 30$, of serotype $\mathrm{O} 26 . \mathrm{H} 11$, could be neutralized by a rabbit antiserum prepared against purified Shiga toxin (O'Brien et al., 1982); this toxin has been termed VT1 (Scotland et al., 1985). A second VT, designated VT2, was first shown in strains of serogroup O157 isolated from cases of HUS and HC (Scotland et al., 1985). Some strains of serogroup O157 produced both VT1 and VT2 while others produced either VT1 or VT2 (Scotland et al., 1985, 1988; Smith et al., 1987). The terms Shiga-like toxins I and II (SLTI and SLTII) have also been used to describe the toxins VT1 and VT2 respectively (Strockbine et al., 1986). A number of strains isolated from calves were reported to produce a cytotoxin neutralized by an antiserum to Shiga toxin (Sherwood et al., 1985). However, a

Abbreviations: VT, Vero cytotoxin; VTEC, Vero-cytotoxin-producing Escherichia coli; SLT, Shiga-like toxin; $\mathbf{S T}_{\mathrm{A}}$, heat-stable enterotoxin; LT, heat-labile enterotoxin; HUS, haemolytic uraemic syndrome; HC, haemorrhagic colitis; DEP, Division of Enteric Pathogens; CVL, Central Veterinary Laboratory. 
subsequent study failed to confirm the neutralization by anti-Shiga toxin of the VT produced by some of these bovine strains (Marques et al., 1986) and showed that the VT produced by strains belonging to serogroups $\mathrm{O} 4, \mathrm{O} 8$ and $\mathrm{O} 149$ was neutralized by antiserum to SLTII (=VT2). VT produced by strains of porcine origin that belonged to serogroups $\mathrm{O} 138, \mathrm{O} 139$ and $\mathrm{O} 141$ could not be neutralized by antisera against VT of $\mathrm{O} 26$ strains of human origin which produce VT1 (Konowalchuk et al., 1977; Smith et al., 1983). However, VT produced by these porcine strains was not tested with an antiserum raised against VT2 as defined with the 0157 strains of human origin.

The genes controlling VT production are phage-encoded in some strains (Scotland et al., 1983; Smith et al., 1983; O'Brien et al., 1984; Smith et al., 1984), and VT sequences have been cloned in $E$. coli $\mathrm{K} 12$ from phage DNA originating in strains producing VT1 or VT2 (Newland et al., 1985; Willshaw et al., 1985, 1987; Huang et al., 1986). Mapping of the cloned VT sequences led to the identification of specific DNA probes for VT1 and VT2 (Willshaw et al., 1985, 1987).

In this paper we have examined the types of VT produced by strains of bovine and porcine origin. VT production was detected using culture supernatants on Vero cells and neutralization experiments were done with rabbit antisera against VT1 and VT2. The strains were tested by colony hybridization with the DNA probes for VT1 and VT2. The sources of the VT1 and VT2 toxins and toxin genes, for the production of antisera and development of DNA probes, were strains of human origin.

\section{METHODS}

Bacterial strains. Twenty VTEC of bovine origin and $14 \mathrm{VT}^{+}$strains of $E$. coli isolated from pigs were examined (Table 1). The organisms were serotyped by the methods of Gross \& Rowe (1985). The bovine strains were from calves with diarrhoea or dysentery: strains E40867, E40868 and E40870 to E40879 were reported as $\mathrm{VT}^{+}$by Sherwood et al. (1985) and strain S102-9 was described by Hall et al. (1985). The remaining bovine strains were from the Division of Enteric Pathogens (DEP) collection. E26817 and E26818 were isolated in Thailand, E37445, E37446 and E37450 were received from Sri Lanka and E7688 and E10394 were isolated in Britain. Five porcine strains, isolated from cases of oedema disease, were from the Central Veterinary Laboratory (CVL) collection: E57, E68II, E145 and G1108E (Sojka, 1965) and P3 (Smith et al., 1983). The remaining strains were received by the CVL between 1981 and 1984 and were from pigs or piglets with diarrhoea with the exception of E40888, serotype O139.H1, which was isolated from a fatal case of bowel oedema. Two strains of human origin were included as controls: strain H19, serotype O26.H11 (VT1) and strain E32511, serotype O157.H- (VT2) (Scotland et al., 1985).

Tests for VT production and neutralization experiments. The method for detecting VT in culture supernatants has been described previously (Scotland et al , 1980). Bacterial cultures were grown with shaking in $10 \mathrm{ml}$ trypticase soy broth at $37^{\circ} \mathrm{C}$ for $18 \mathrm{~h}$. After centrifugation and filtration, sterile supernatants were added to monolayers of Vero cells grown in microtitre plates. The plates were incubated at $37^{\circ} \mathrm{C}$ for $4 \mathrm{~d}$, stained and examined for any cytotoxic effect. Toxin titres were the highest dilution giving a cytotoxic effect on Vero cells after $4 \mathrm{~d}$ incubation. Antisera were prepared against partially purified VT1 from strain H19 and VT2 from strain E32511 by the method of Konowalchuk et al. (1978): these antisera do not cross-react (Scotland et al., 1985). The VT1 antiserum gave the same results as those obtained with an antiserum raised to purified Shiga toxin kindly provided by $\mathrm{Dr} A$. D. O'Brien (Uniformed Services University, Bethesda, Md., USA). Neutralization experiments were done as described by Scotland et al. (1988).

Tests for production of heat-stable enterotoxin $\left(S T_{A}\right)$ and heat-labile enterotoxin $(L T)$. All $\mathrm{VT}^{+}$strains were tested for production of $\mathrm{ST}_{\mathrm{A}}$, detectable in the infant mouse assay, and LT (Gross et al., 1976).

DNA hybridization experiments. Strains were prepared for colony hybridization as described by Willshaw et al. (1985) on nylon membranes (Hybond-N, Amersham). The cloning of VT1 and VT2 sequences and the development of specific gene probes has been described previously (Willshaw et al., 1985, 1987). The VT1 probe was a $0.75 \mathrm{~kb}$ HincII fragment derived from the VT-encoding phage isolated from strain $\mathrm{H} 19$. The VT2 probe was a $0.85 \mathrm{~kb}$ AvaI-Pst I fragment present in VT2 sequences cloned from the VT2-encoding phage in strain E32511. The DNA fragments were purified from vector DNA, labelled and used in hybridization experiments under 'stringent' conditions as described previously (Willshaw et al., 1985).

\section{RESULTS}

\section{DNA hybridization experiments}

All the $\mathrm{VT}^{+}$strains of bovine or porcine origin hybridized with either the VT1 or the VT2 probe (Table 1). Fourteen of the twenty calf strains were detected with the VT1 probe including 
Table 1. Properties of $V T^{+}$E. coli of animal origin

The toxin titrations were done in at least two separate experiments. NT, Not tested.

\begin{tabular}{|c|c|c|c|c|c|c|}
\hline \multirow[b]{3}{*}{ Serotype* } & \multirow{3}{*}{$\begin{array}{c}\text { DEP } \\
\text { no. }\end{array}$} & \multirow{2}{*}{\multicolumn{2}{|c|}{ with DNA probes }} & \multicolumn{3}{|c|}{ roxin titie } \\
\hline & & & & \multirow{2}{*}{$\begin{array}{l}\text { Without } \\
\text { antiserum }\end{array}$} & \multirow{2}{*}{$\begin{array}{c}\text { With antiserum } \\
\text { to VT1 }\end{array}$} & \multirow{2}{*}{$\begin{array}{c}\text { With antiserum } \\
\text { to VT2 }\end{array}$} \\
\hline & & VT1 & VT2 & & & \\
\hline \multicolumn{7}{|l|}{ Bovine strains } \\
\hline $\mathrm{O} 2 . \mathrm{H} 7$ & E26817† & - & + & 1250 & NT & NT \\
\hline $\mathrm{O} 2 . \mathrm{H} 7$ & E26818t & - & + & 250 & NT & NT \\
\hline $\mathrm{O} 5 . \mathrm{H}^{-}$ & S102-9 & + & - & 6250 & NT & NT \\
\hline O8.H9 & E40873 & - & + & 250 & 250 & 0 \\
\hline $\mathrm{O} 26 . \mathrm{H} 11$ & E7688 & + & - & 6250 & NT & NT \\
\hline $\mathrm{O} 26 . \mathrm{H} 11$ & E10394 & + & - & 31250 & NT & NT \\
\hline $\mathrm{O} 26 . \mathrm{H} 11$ & E40877 & + & - & 1250 & 0 & 1250 \\
\hline O26.H11 & E40878 & + & - & 156250 & 1250 & 156250 \\
\hline O29.H34 & E37445 & + & - & 31250 & 50 & 31250 \\
\hline O55.H17 & E37446 & + & - & 250 & NT & NT \\
\hline O111 ac. $\mathrm{H}^{-}$ & E40867 & + & - & 1250 & 10 & 1250 \\
\hline Olllac.H ${ }^{-}$ & E40875 & + & - & 6250 & 50 & 6250 \\
\hline Olllac. $\mathrm{H}^{-}$ & E40876 & + & - & 6250 & 250 & 6250 \\
\hline O149.H? & E40879 & - & + & 160 & 160 & 10 \\
\hline $\mathrm{O} 153 . \mathrm{H} 12$ & E37450 & + & - & 250 & NT & NT \\
\hline $\mathrm{O}$ rough & E40868 & - & + & 31250 & 31250 & 0 \\
\hline $\mathrm{O} ? \mathrm{H} 25$ & E40874 & - & + & 156250 & 156250 & 250 \\
\hline $\mathrm{O} ? \mathrm{H}^{-}$ & $\mathrm{E} 40870$ & + & - & 1250 & 50 & 1250 \\
\hline $\mathrm{O} ? \mathrm{H}^{-}$ & E40871 & + & - & 1250 & 50 & 1250 \\
\hline $\mathrm{O} ? \mathrm{H}^{-}$ & E40872 & + & - & 250 & 10 & 250 \\
\hline \multicolumn{7}{|l|}{ Porcine strains } \\
\hline O65.H9 & E40896 & - & + & 10 & 10 & 0 \\
\hline O65.H9 & E40897 & - & + & 40 & 40 & 0 \\
\hline O65.H9 & E40898 & - & + & 10 & 10 & 0 \\
\hline O65.H9 & E40899 & - & + & 20 & 20 & 0 \\
\hline O65.H9 & E40900 & - & + & 160 & 160 & 0 \\
\hline O138.H14 & E40893 & - & + & 20 & 20 & 0 \\
\hline O138. $\mathrm{H}^{-}$ & E57† & - & + & 160 & 160 & 0 \\
\hline $\mathrm{O} 138 . \mathrm{H}^{-}$ & E40901† & - & + & 40 & 40 & 0 \\
\hline OI $39 . \mathrm{HI}$ & P3 & - & + & 20 & 20 & 0 \\
\hline O139.H1 & E40888 & - & + & 40 & 40 & 0 \\
\hline O141.H4 & E145 & - & + & 80 & 80 & 0 \\
\hline O141.H4 & E68II & - & + & 10 & 10 & 0 \\
\hline O141.H4 & E40891 & - & + & 80 & 80 & 0 \\
\hline O? H4 & G1108E $+\ddagger$ & - & + & 80 & 80 & 0 \\
\hline
\end{tabular}

the four strains of serotype $\mathrm{O} 26 . \mathrm{H} 11$ and three belonging to serogroup $\mathrm{O} 111$. Four bovine strains hybridizing with the VT2 probe belonged to serogroups $\mathrm{O} 2, \mathrm{O} 8$ and $\mathrm{O} 149$ and the remaining two could not be serotyped.

The VTEC isolated from pigs belonged to four different $O$ serogroups $(65,138,139$ and 141) and one was unidentifiable; all strains hybridized with the VT2 probe only. Six of the strains of serogroups $\mathrm{O} 138, \mathrm{O} 139$ and $\mathrm{O} 141$ were isolated from cases of oedema disease whereas the other strains were from piglets or weaned pigs with diarrhoea.

\section{Toxin titres and neutralization experiments}

Culture supernatants of all the strains were examined for the level of VT production using Vero cells (see Methods). The VT titres of the calf strains ranged from 160 to 156250 (Table 1) but the level of VT production did not correlate with the presence of either VT1 or VT2; for 
example, strains E40878 and E40874 gave the highest titres of 156250 and produced VT1 and VT2 respectively. Neutralization experiments using antisera to VT1 or VT2 were in agreement with the results of the DNA hybridization in all cases tested. In some tests with the bovine strains there was incomplete neutralization of toxin activity that may have occurred because there was insufficient antibody in these experiments.

The VT titres of the porcine strains were much lower than those of the VTEC from calves; the titres ranged from 10 to 160 . All these strains hybridized with the VT2 probe and toxin activity was neutralized in all cases with the antiserum to VT2 but not with the VT1 antiserum. No relationship was observed between the amount of VT produced and the strength of the hybridization signal.

Two bovine strains and two porcine strains produced $\mathrm{ST}_{\mathrm{A}}$ in addition to VT and strain G1108E, of porcine origin, produced both $\mathrm{ST}_{\mathrm{A}}$ and LT as well as VT (Table 1).

\section{DISCUSSION}

The results show that the VTs and VT genes of the 34 strains of animal origin could be identified with antisera and DNA probes developed using strains producing VT1 or VT2 of human origin. Most of the $\mathrm{VT}^{+}$animal strains described in this paper belong to serogroups not usually associated with VTEC of human origin, the exceptions being strains of serogroups O26, $\mathrm{O} 111$ and $\mathrm{O} 153$ that have been isolated from both human and bovine infections (Scotland et al., 1980, 1988; Karmali et al., 1983; Sherwood et al., 1985).

Preliminary studies at the CVL on strains from animals with diarrhoea showed that VTEC were detected in $22 \%$ of 237 porcine strains and $8 \%$ of $85 \mathrm{E}$. coli from cattle. (C. Wray \& I. M. McLaren, unpublished). By comparing isolation rates of VTEC in animals with and without diarrhoea in Sri Lanka, Mohammad et al. (1985) showed a significant association between VT production and diarrhoea in cattle and buffalo calves. The VT probes could be used in further studies to investigate the role of VTEC in animal disease. The bovine strain S102-9, serotype $\mathrm{O} 5 . \mathrm{H}^{-}$, has been used in studies with experimental animals. This strain, which produces VT1 and was isolated from calves with dysentery (Hall et al., 1985), caused a disease in experimental animals that was indistinguishable from the natural infection. The VTEC most commonly associated with human disease belong to serogroup $\mathrm{O} 157$ and such strains have been isolated from milk and healthy cattle associated with O157.H7 human infection in North America (Martin et al., 1986; Borczyk et al., 1987). Recently, it has been reported that O157.H7 VTEC isolated in Argentina in 1977 were found in a diseased calf (Orskov et al., 1987). It was suggested that cattle may be primary reservoirs of VTEC serotype O157.H7 that are associated with human disease.

The production of VT by the porcine strains was very low so the use of DNA probes provided a useful method for examining such strains for the presence of genes for VT1 or VT2. Previous studies (Konowalchuk et al., 1977; Smith et al., 1983) showed that porcine strains produce a VT immunologically unrelated to the VT of some human strains examined by these workers, and now known to be VT1. Our finding that porcine strains produce VT2 confirm these early observations. We have found VT2 production also in human strains belonging to several serogroups but none was in common with those of the porcine strains (Scotland et al., 1985, 1988; Smith et al., 1987). Animal studies have suggested that VT may be important in oedema disease of pigs. Fourteen pigs were injected with extracts of $E$. coli K12 strains producing VT and ten of the animals developed clinical signs of oedema disease (Smith et al., 1983). Dobrescu (1983) showed that 'oedema disease principle' extracted from porcine strains was cytotoxic for Vero cells but it was not neutralized by an antiserum to VT1. In the present study, we have shown that two of the strains used by Dobrescu, E57 and E68II, produce VT2. Further studies with VT2 toxin should be useful in showing whether this toxin is an aetiological factor in oedema disease.

It appears that VTEC of animal origin are associated with different clinical symptoms: diarrhoea, dysentery and oedema disease. VTEC of human origin, particularly strains of serogroup 0157 , are also associated with a spectrum of clinical manifestations from mild 
diarrhoea to serious conditions such as HUS. Even within an outbreak of O157.H7 infection in a nursing home there were patients with asymptomatic infection, non-bloody diarrhoea, $\mathrm{HC}$ and HUS (Ryan et al., 1986). In some studies of HUS it has been observed there are patients suffering from disorientation and seizures and also peripheral oedema (Karmali et al., 1985). This suggests that there are similarities between HUS and oedema disease in pigs in which ataxia and mental confusion are prominent features (Sojka, 1965; Smith et al., 1983). Studies on the role of Shiga toxin in disease have demonstrated that cytotoxic, enterotoxic and paralytic lethal effects are all due to a single purified toxin (review, O'Brien \& Holmes, 1987). Both VT1 and VT2 also have these three properties (O'Brien et al., 1982; Strockbine et al., 1986; O'Brien \& Holmes, 1987) and this may explain why VTEC are associated with several different clinical conditions. In addition production of $\mathrm{ST}_{\mathrm{A}}$ or $\mathrm{LT}$ by some of the animal VTEC is also likely to be important in the observed clinical symptoms.

Results of this and previous studies suggest that VT1 and VT2 are important in both animal and human infections. Further studies are required to trace the sources of infection and also to examine VT production of the animal strains in more detail.

\section{REFERENCES}

Blanco, J., Gonzalez, E. A., Bernardez, I. \& REGUEIRO, B. (1983). Differentiated biological activity of Vero cytotoxin (VT) released by human and porcine Escherichia coli strains. FEMS Microbiology Letters 20, 167-170.

BorczyK, A. A., Karmali, M. A., Lior, H. \& Duncan, L. M. C. (1987). Bovine reservoir for Verotoxin-producing Escherichia coli O157.H7. Lancet $\mathrm{i}, 98$.

DOBRESCU, L. (1983). New biological effect of edema disease principle (Escherichia coli neurotoxin) and its use as an in vitro assay for this toxin. American Journal for Veterinary Research 44, 31-34.

Gonzalez, E. A. \& Blanco, J. (1985). Production of cytotoxin VT in enteropathogenic and non-enteropathogenic Escherichia coli strains of porcine origin. FEMS Microbiology Letters 26, 127-130.

Gross, R. J. \& Rowe, B. (1985). Serotyping of Escherichia coli. In The Virulence of Escherichia coli. Reviews and Methods, pp. 345-363. Edited by M. Sussman. London: Academic Press.

Gross, R. J., Scotland, S. M. \& Rowe, B. (1976). Enterotoxin testing of Escherichia coli causing epidemic infantile enteritis in the UK. Lancet i, 629631.

hall, G. A., Reynolds, D. J., Chanter, N., Morgan, J. H., Parsons, K. R., Debney, T. G., BlaND, A. P. \& BRIDGer, J. C. (1985). Dysentery caused by Escherichia coli (S102-9) in calves: natural and experimental disease. Veterinary Pathology 22, 156-163.

huang, A., DeGrandis, S., Friesen, J., Karmali, M., Petric, M., Congi, R. \& Brunton, J. L. (1986). Cloning and expression of the genes specifying Shiga-like toxin production in Escherichia coli $\mathrm{H} 19$. Journal of Bacteriology 106, 375-379.

Karmali, M. A., Steele, B. T., Petric, M. \& Lim, C. (1983). Sporadic cases of haemolytic uraemic syndrome associated with faecal cytotoxin and cytotoxin-producing Escherichia coli in stools. Lancet $\mathbf{i}$, 619-620.

Karmali, M. A., Petric, M., Lim, C., Fleming, P. C.,
ARBUS, G. S. \& LIOR, H. (1985). The association between idiopathic hemolytic uremic syndrome and infection by Verotoxin-producing Escherichia coli. Journal of Infectious Diseases 151, 775-782.

Karmali, M. A., Petric, M., Louie, S. \& Cheung, R. (1986). Antigenic heterogeneity of Escherichia coli Verotoxins. Lancet i, 164-165.

Kashiwazaki, M., OGawa, T., Isayama, Y., AKaike, Y., TAMURA, K. \& SaKaZaKi, R. (1980). Detection of Vero cytotoxin strains of Escherichia coli isolated from diseased animals. National Institute of Animal Health Quarterly 20, 116-117.

Kashiwazaki, M., Ogawa, T., Nakamura, K., IsWyama, T., Tamura, K. \& SaKazaki, R. (1981). Vero cytotoxin produced by Escherichia coli strains of animal origin. National Institute of Animal Health Quarterly 21, 69-72.

KonowalchuK, J., Speirs, J. I. \& Stavric, S. (1977). Vero response to a cytotoxin of Escherichia coli. Infection and Immunity 18, 775-779.

KonowalchuK, J., Dickie, N., Stavric, S. \& Speirs, J. I. (1978). Properties of an Escherichia coli cytotoxin. Infection and Immunity 20, 575-577.

Marques, L. R. M., Moore, M. A., Wells, J. G., Wachsmuth, K. \& O'Brien, A. D. (1986). Production of Shiga-like toxin by Escherichia coli. Journal of Infectious Diseases 154, 338-341.

Martin, M. L., Shipman, L. D., Wells, J. G., Putter, M. E., Hedberg, K., Wachsmuth, I. K., TAuXe, R. V., Davis, J. P., ARnoldi, J. \& Tilleli, J. (1986). Isolation of Escherichia coli O157.H7 from dairy cattle associated with two cases of haemolytic uraemic syndrome. Lancet ii, 1043.

Mohammad, A., Peiris, J. S. M., Wijewanta, E. A., Mahalingam, S. \& Gunasekara, G. (1985). Role of verocytotoxigenic Escherichia coli in cattle and buffalo calf diarrhoea. FEMS Microbiology Letters 26, 281-283.

Mohammad, A., Peiris, J. S. M. \& Wijewanta, E. A. (1986). Serotypes of verocytotoxigenic Escherichia coli isolated from cattle and buffalo calf diarrhoea. FEMS Microbiology Letters 35, 261-265. 
Newland, J. W., Strockbine, A. A., Miller, S. F., O'Brien, A. D. \& Holmes, R. K. (1985). Cloning of Shiga-like toxin structural genes from a toxin converting phage of Escherichia coli. Science 230, 179-181.

O'BRIEN, A. D. \& Holmes, R. K. (1987). Shiga and Shiga-like toxins. Microbiological Reviews 51, 206220.

O'Brien, A. D., LaVeck, G. D., Thompson, M. R. \& Formal, S. B. (1982). Production of Shigella dysenteriae type 1-like cytotoxin by Escherichia coli. Journal of Infectious Diseases 146, 763-769.

O'Brien, A. D., Newland, J. W., Miller, S. F., Holmes, R. K., Williams Smith, H. \& Formal, S. B. (1984). Shiga-like toxin-converting phages from Escherichia coli strains that cause hemorrhagic colitis or infantile diarrhoea. Science 226, 694-696.

Orskov, F., Orskov, I. \& VillaR, J. A. (1987). Cattle as reservoir of Verotoxin-producing Escherichia coli O157.H7. Lancet ii, 276.

Riley, L. W., Remis, R. S., Helgerson, S. D., MCGeE, H. B., Wells, J. G., Davis, B. R., Hebert, R. J., Olcott, E. S., Johnson, L. M., HaRgretT, N. T., Blake, P. A. \& COHEN, M. L. (1983). Hemorrhagic colitis associated with a rare Escherichia coli serotype. New England Journal of Medicine 308, 681-685.

Ryan, C. A., TauXe, R. V., Hosek, G. W., Wells, J. G., Stoesz, P. A., McFadden, H. W., Smith, P. W., Wright, G. F. \& Blake, P. A. (1986). Escherichia coli $\mathrm{O} 157 . \mathrm{H} 7$ diarrhoea in a nursing home: clinical, epidemiological and pathological findings. Journal of Infectious Diseases 154, 631-638.

Scotland, S. M., Day, N. P. \& Rowe, B. (1980). Production of cytotoxin affecting Vero cells by strains of Escherichia coli belonging to traditional enteropathogenic serogroups. FEMS Microbiology Letters 7, 15-17.

Scotland, S. M., Smith, H. R., Willshaw, G. A. \& Rowe, B. (1983). Vero cytotoxin production in strain of Escherichia coli is determined by genes carried on bacteriophage. Lancet ii, 216.

SCOTland, S. M., Smith, H. R. \& Rowe, B. (1985). Two distinct toxins active on Vero cells from Escherichia coli 0157. Lancet ii, 885-886.
Scotland, S. M., Rowe, B., Smith, H. R., Willshaw, G. A. \& Gross, R. J. (1988). Vero cytotoxinproducing strains of Escherichia coli from children with haemolytic uraemic syndrome and their detection by specific DNA probes. Journal of Medical Microbiology 25, (in the Press).

Sherwood, D., Snodgrass, D. R. \& O'Brien, A. D. (1985). Shiga-like toxin production from Escherichia coli associated with calf diarrhoea. Veterinary Record 116, 217-218.

Smith, H. R., Day, N. P., Scotland, S. M., Gross, R. J. \& Rowe, B. (1984). Phage-determined production of Vero cytotoxin in strains of Escherichia coli serogroup O157. Lancet i, 1242-1243.

SMith, H. R., Rowe, B., Gross, R. J., FrY, N. K. \& Scotland, S. M. (1987). Haemorrhagic colitis and Vero cytotoxin-producing Escherichia coli in England and Wales. Lancet i, 1062-1065.

Smith, H. W., Green, P. \& Parsell, Z. (1983). Vero cell toxins in Escherichia coli and related bacteria: transfer by phage and conjugation and toxic action in laboratory animals, chickens and pigs. Journal of General Microbiology 129, 3121-3137.

SoJKA, W. J. (1965). Escherichia coli in Domestic Animals and Poultry. Farnham Royal: Commonwealth Agricultural Bureaux.

Strockbine, N., Marques, L. R. M., Newland, J. W., Smith, H. W., Holmes, R. K. \& O'Brien, A. D. (1986). Two toxin-converting phages from Escherichia coli $0157 . \mathrm{H} 7$ strain 933 encode antigenically distinct toxins with similar biologic activities. Infection and Immunity 53, 135-140.

Willshaw, G. A., Smith, H. R., Scotland, S. M. \& Rowe, B. (1985). Cloning of genes determining the production of Vero cytotoxin by Escherichia coli. Journal of General Microbiology 131, 3047-3053.

Willshaw, G. A., Smith, H. R., Scotland, S. M., FIELD, A. M. \& RowE, B. (1987). Heterogeneity of Escherichia coli phages encoding Vero cytotoxins: comparison of cloned sequences determining VT1 and VT2 and development of specific gene probes. Journal of General Microbiology 133, 1309-1317. 